\title{
Nutrient Composition of Steam Cooked Pangasius Meat and Their Analysis of Proximate, Fatty Acid and Mineral Composition
}

\author{
S. Kothandaperumal ${ }^{1}$, S. Dhaarnishwara ${ }^{1}$, A. Revathi $^{2}$, T. S. Inbavalli ${ }^{2}$ \\ ${ }^{1}$ Department of Fish Processing Technology, Fisheries College and Research Instutite, Thoothukudi, India \\ ${ }^{2}$ Department of Zoology, University of Madras, Chennai, India
}

Email address:

fishcoperumal@gmail.com (S. Kothandaperumal)

\section{To cite this article:}

S. Kothandaperumal, S. Dhaarnishwara, A. Revathi, T. S. Inbavalli. Nutrient Composition of Steam Cooked Pangasius Meat and Their Analysis of Proximate, Fatty Acid and Mineral Composition. Advances in Biochemistry. Vol. 9, No. 3, 2021, pp. 50-55.

doi: $10.11648 /$ j.ab.20210903.13

Received: June 13, 2021; Accepted: June 23, 2021; Published: August 19, 2021

\begin{abstract}
The aim of this research has to be removal of saturated and mono-unsaturated fatty acid it was done by steaming method. After deafatted meat were analyse the nutritional compositions. Catfish essential fatty acid is low because of a small amount of n-3 family PUFA and high amount of MUFA and SFA. The SFA and trans C18: 1 MUFA can increase risk of chronic cardiovascular diseases that affects the heart, blood vessels, and brain. Effective processing of heat treatment method can get reduced of the fat content in Pangasius catfish fillet in this meat was contain essential proteins and provide a good protein food for consumers. The present project is therefore proposed to develop a suitable preprocessing method for removal of fat from catfish fillets. normal steam pressure cooking method as used heat treatment such as steam cooked method were used to reduce in the SFA and MUFA content of fish fillets. The present research is proposed to study the proximate composition, fatty acid composition and minerals composition of steam defatted fillets. This chemical composition such as mainly had studied about mineral such as sodium, iron, phosphorus, calcium, magnesium and zinc. Fatty acid composition has been studied about saturated and mono-unsaturated fatty acid it is rendered to produced free fatty acid oxidized odour it can be produced off-flavour of the products it were removed by different heat treatment were conducted by microwave energy treatment and grilled and steam heat treatment it was reduced to saturated and monounsaturated fatty acid and is this was increased about poly-unsaturated fatty acid and provide to nutritional stuff for human begins.
\end{abstract}

Keywords: Fish Meat, Steaming Method, Proximate Composition, Fatty Acid Composition, Mineral Composition

\section{Introduction}

Pangasius genus includes the catfish varieties that are commonly found in the south-east Asian region. It belongs to the family Pangasiidae. The most common variety of cultured fish is Pangasianodon hypophthalmus. This fish species is also called, Sutchi catfish, striped catfish, or Tra fish. Among all the freshwater species, Pangasius catfish is the world's fastest-growing species in aquaculture. Pangasius is now traded worldwide as skinless and boneless fillets popularly along with portions, steaks, fillets, and also as value-added products $[1,2]$. The fish attains a bodyweight of 1.2 to $1.3 \mathrm{~kg}$ rapidly within six months but usually harvested after eight months of culture. There is a tremendous demand for fish-based products, especially value-added products such as ready-to-eat "convenience" products. The filleting industry produces significant amounts of head, bone, scrap meat, and skin by-products. By way of proper processing, it can be converted to various high-value products, and it has good economic efficiency. The utilization of Pangasius fish waste is an excellent potential source for value-added products. Studies on the development of Pasta products from Pangasius fish are detailed below. Pangasius fillets are a good substitute for white-fleshed fishes in the market due to their increasing acceptability and popularity; Pangasius is usually served in the European market as skinned and boneless frozen fillets [3]. Currently, these fillets exported to over 100 countries worldwide. Fillets were characterized by high moisture levels 
of $80 \%$ and low crude protein of $15.8 \%$ and lipid of $3.0 \%$ contents. Total lipids were characterized by low cholesterol levels of $40 \mathrm{mg} / 100 \mathrm{~g}$, high percentages of saturated fatty acids $(47.5 \%)$ of total fatty acid. Low percentages of polyunsaturated fatty acids $(20 \%)$ are present in total fatty acids mainly represented by linoleic acid $(60 \%$ of total polyunsaturated fatty acids).

The mineral composition was characterized by a high sodium content of about $595 \mathrm{mg} / 100 \mathrm{~g}$ [4]. The pasta is mainly prepared from wheat flour, which contains about 10 $15 \mathrm{~g} / 100 \mathrm{~g}$ of protein but there is a lack of essential amino acids, making it an incomplete protein. To compensate for the lack of protein in the pasta, fish protein can serve as an excellent source of proteins as they contain all the essential amino acids with excellent digestibility and it is efficiently available in low cost. Pangasius is a majorly cultured freshwater fish species in India; it is a rich source of proteins and other nutrients. Pangasius fillet contains a considerable amount of rich fatty acids and proteins. This work is mainly focused on study of nutritional composition such as proximate, fatty acid and mineral composition [5].

\section{Materials and Methods}

\subsection{Materials}

Pangasius hypophthalmus were collected from Madurai AM fish farm and fish markets. The collected fishes were kept in insulated iceboxes. Insulated icebox prevents dehydration, and temperature fluctuation thus delays the spoilage of fish. Further, it is easy to handle. Flake ice produced by flake ice machine was used during fish transportation and processing purpose.

Size of the ice for $2-3 \mathrm{~cm}$ level were produced to kept into the box and fish were spread on ice layer then carried out further steps.

\subsection{Method}

\subsubsection{Sampling Procedure}

Randomly samples were chosen and analyzed for proximate, fatty acid composition (PUFA) and mineral composition. Samples were collected from raw fillets and steam cooked meat.

\subsubsection{Proximate Composition Analysis}

The protein, fat, ash, water and carbohydrate content were analyzed by AOAC methods 2000 [6]. 1 gram wet sample need for analysis of protein content, 4.5-5 gram of samples are used to estimate of the fat content, 2 gram of dry sample are used to estimate of the ash and 10 gram of wet samples are used to analysis of the moisture content. The protein content of raw fillet, cooked meat and pasta product was analyzed by the Kjeldahl method, 1883 [7]. The digester temperature was followed at 300 to $400^{\circ} \mathrm{C}$ and distillation process was run for 8 minutes. The fat content of raw fillet, cooked meat and pasta product was analysed by Folch methods (1957), [8]. The moisture content of raw meat, cooked meat and pasta products were analysed by AOAC methods (2000). The samples were kept in hot air oven for 12 hours at $100^{\circ} \mathrm{C}$. Ash content of raw meat, cooked meat and pasta products were analysed by AOAC methods (2000). The samples were kept in muffle furnace for 24 hours at $550^{\circ} \mathrm{C}$. The carbohydrate content of raw meat, cooked meat and pasta products were analysed by different methods.

The protein estimated chemicals are inclusion of sulfuric acid, digestion mixture: copper sulfate- $0.1 \mathrm{~g}$ and potassium sulfate- $2.5 \mathrm{~g}$ for each sample, sodium hydroxide, $40 \%$, boric acid, 4\%, mixed indicator: methyl red-0.16 $\mathrm{g}$ and bromocresol green- $80 \mathrm{mg}$ in $100 \mathrm{ml}$ of $95 \%$ ethanol and standard sulfuric acid $0.1 \mathrm{~N}$. analyzed fat composition was used chemicals inclusion of chloroform and methanol (2:1) and potassium chloride (KCL), $0.74 \%$. and one more method of soxhlet used in $80 \mathrm{ml}$ of petroleum ether. crude fiber analyzed chemical inclusion of sulfuric acid $1.25 \%$ and sodium hydroxide $1.25 \%$ and petroleum ether $40-60^{\circ} \mathrm{C}$.

\subsubsection{Fatty Acid Composition Analysed by Gas Chromatography}

Fatty acid is very important components of lipids content. GC is most common method used for analysis of fatty acid composition. The fatty acid is a complex structure. It contains more components of fatty acid such as acylglycerols, cholesterol esters, waxes and glycsosphingolipds. It is extracted b saponification hydrolysis it is done by alkaline medium AOAC, 1990. The FAMEs are extracted by use of the methanol and boron trifluoride. Extraction and methylation it is done by folch method are used to obtained the lipid components from the ten gram of fish samples. Esterification was done, take $250 \mathrm{~g}$ lipid fraction it is dissolved in to toluene in the round bottom flask. Then, added $4 \mathrm{ml}$ sodium hydroxide and reflux for 5-10 minutes until droplets of fat disappears. added $5 \mathrm{ml}$ of methanol and reflux for another $1 \mathrm{~min}$. cool the content and add $15 \mathrm{ml}$ of saturated sodium chloride solution. then, add $5 \mathrm{ml}$ of hexane, shake well and then remove the upper layer hexane layer. Repeat the extraction with hexane twice. It is combine hexane layer and evaporate to dryness in a rotary flask evaporator set at $55-60^{\circ} \mathrm{C}$. The methyl esters in 1 $\mathrm{ml}$ of HPLC grade hexane for injection in GC. The column at $210^{\circ} \mathrm{C}$ for 30 minutes. then, inject $0.5 \mathrm{ml}$ of standard FAMEs mixture onto the GC. Then, it is start to separation of FAMEs takes $45 \mathrm{~min}$.

Next, inject $0.5 \mathrm{ml}$ of sample FAMEs. Identify the individual fatty acid in the sample by comparing the retention time of the individual fatty acid in the standard mixture. calculated area unit value expressed to percentage of the fatty acid of total lipids.

\subsubsection{Mineral Composition Analysis}

Some vital macro and trace mineral content of raw meat, cooked meat, and pasta products was analysed by titrations methods. Titration methods were used to analyses of samples. $\mathrm{Ca}, \mathrm{Mg}, \mathrm{Fe}, \mathrm{Zn}, \mathrm{Na}$ and $\mathrm{P}$ contents of raw and defatted meats. $\mathrm{Ca}, \mathrm{Mg}$ and $\mathrm{Zn}$ was analysed by EDTA titration method. sodium done by flame photometer, phosphorous was done by amino naphthol sulphonic acid and 
iron was done by 1:10 phenanthrolene.

Calculation: $(\mathrm{mg} / 100 \mathrm{~g})=\mathrm{T} . \mathrm{V} \times \mathrm{N} \times 100 \times \mathrm{D} . \mathrm{F} / \mathrm{W} \times 0.05$

\subsection{Statistical Analysis}

The SPPS 19 (IBM, 2010) statistical package was used for analysis of experimental results. The results were produced in the mean standard deviation.

\section{Result and Discussion}

\subsection{Proximate Composition of Raw and Defatted Pangasius Fillets}

Steam cooked methods of the heat treatment used to remove the fat content of the fish fillets with minimal nutritional damage. The proximate composition of the raw, steam, methods was studied.

Those were estimated for the content of the moisture, protein, fat and ash, $72.12 \pm 0.68 \% 21.52 \pm 0.60 \%$, $4.32 \pm 071 \%$ and $1.31 \pm 0.065 \%$ and $69.94 \pm 1.014 \%$, $24.52 \pm 0.48 \%, 4.93 \pm 0.266 \%$ and $1.43 \pm 0.225 \%$ and $70.93 \pm 2.571 \%, \quad 23.85 \pm 0.911 \%, \quad 3.87 \pm 1.036$ and $1.31 \pm 0.052 \%$ and $66.54 \pm 0.373 \%, 25.88 \pm 0.802 \%$, $7.06 \pm 0.332$ and $1.53 \pm 0.141 \%$ was reported [9]. This study was expressed after heat treatment and there was increase in content of the protein, fat and ash and decrease in moisture content which was reported [10].

The present study the Pangasius fish fillets were used to remove the fat content, the fat content SFA and MUFA could be reduced or removed by use of the different heat treatment method such as the microwave, grilled and steam method. The proximate composition of the steam cooked fillets of the head, body, ventral and tail portions was estimated as moisture, protein, fat, ash and carbohydrate from head portion- $69.86 \%, 25.16 \%, 2.45 \%, 1.87 \%$ and $0.64 \%$, body portion- $69.56 \%, 25.24 \%, 2.23 \%, 1.83 \%$ and $1.13 \%$, ventral region- $69.25 \%, 25.26 \%, 2.36 \%, 1.79 \%$ and $1.32 \%$ and tail portion- $67.02 \%, 25.16 \%, 2.17 \%, 1.96 \%$ and $1.67 \%$. The proximate composition of the steam cooked meat is found to be in the range of up to $98.54 \%$. The fat, moisture, protein, ash and carbohydrate content could be increased or decreased is based on the portion of meat. ANOVA test was applied to analyze the sample variation between the samples. Degrees of freedom 2. T-test was applied there is no significant difference between samples and F-test was applied there was little significance variation between samples. F- test not that much variation between the samples. $0.1 \%$ it means only one percent changes from 100 percentages of samples.

Table 1. Steam cooked Pangasius head portion).

\begin{tabular}{lllll}
\hline Composition & Sample-1 & Sample-2 & Sample-3 & Total/average \\
\hline Moisture & $69.84 \%$ & $69.87 \%$ & $69.87 \%$ & $69.86 \pm 0.0000 .000$ \\
Protein & $25.18 \%$ & $25.14 \%$ & $25.18 \%$ & $25.16 \pm 0.0000 .000$ \\
Fat & $2.43 \%$ & $2.47 \%$ & $2.47 \%$ & $2.45 \pm 0.0000 .000$ \\
Ash & $1.89 \%$ & $1.89 \%$ & $1.84 \%$ & $1.87 \pm 0.0000 .000$ \\
carbohydrate & $0.66 \%$ & $0.63 \%$ & $0.64 \%$ & $0.64 \pm 0.0000 .000$ \\
\hline
\end{tabular}

Table 2. Steam cooked Pangasius body portion).

\begin{tabular}{lllll}
\hline Composition & Sample-1 & Sample-2 & Sample-3 & Total/average \\
\hline Moisture & $69.56 \%$ & $69.57 \%$ & $69.57 \%$ & $69.56 \pm 0.0000 .000$ \\
Protein & $25.23 \%$ & $25.26 \%$ & $25.23 \%$ & $25.24 \pm 0.0010 .001$ \\
Fat & $2.23 \%$ & $2.23 \%$ & $2.23 \%$ & $2.23 \pm 0.0003 \pm 0.000$ \\
Ash & $1.83 \%$ & $1.84 \%$ & $1.83 \%$ & $1.83 \pm 0.0000 .000$ \\
carbohydrate & $1.15 \%$ & $1.10 \%$ & $1.14 \%$ & $1.13 \pm 0.0000 .000$ \\
\hline
\end{tabular}

Table 3. Steam cooked Pangasius ventral portion).

\begin{tabular}{lllll}
\hline Composition & Sample-1 & Sample-2 & Sample-3 & Total/average \\
\hline Moisture & $69.25 \%$ & $69.27 \%$ & $69.25 \%$ & $69.25 \pm 0.0000 .000$ \\
Protein & $25.28 \%$ & $25.26 \%$ & $25.26 \%$ & $25.26 \pm 0.0010 .001$ \\
Fat & $2.35 \%$ & $2.35 \%$ & $2.38 \%$ & $2.36 \pm 0.0000 .000$ \\
Ash & $1.79 \%$ & $1.80 \%$ & $1.80 \%$ & $1.79 \pm 0.0000 .000$ \\
carbohydrate & $1.33 \%$ & $1.32 \%$ & $1.31 \%$ & $1.32 \pm 0.0000 .000$ \\
\hline
\end{tabular}

Table 4. Steam cooked Pangasius tail portion).

\begin{tabular}{lllll}
\hline Composition & Sample-1 & Sample-2 & Sample-3 & Total/average \\
\hline Moisture & $69.02 \%$ & $69.04 \%$ & $69.02 \%$ & $69.02 \pm 0.0000 .000$ \\
Protein & $25.17 \%$ & $25.17 \%$ & $25.14 \%$ & $25.16 \pm 0.0010 .001$ \\
Fat & $2.19 \%$ & $2.19 \%$ & $2.15 \%$ & $2.17 \pm 0.0000 .000$ \\
Ash & $1.98 \%$ & $1.98 \%$ & $1.94 \%$ & $1.96 \pm 0.0000 .000$ \\
carbohydrate & $1.64 \%$ & $1.62 \%$ & $1.75 \%$ & $1.67 \pm 0.0000 .000$ \\
\hline
\end{tabular}

Table 5. Steam cooked Pangasius head portion).

\begin{tabular}{lll}
\hline Steam cooked head Sample & T-test & F-test \\
\hline Moisture & 0.000 & 0.1 \\
Protein & 0.000 & 0.2 \\
Fat & 0.000 & 0.6 \\
Ash & 0.000 & 0.0 \\
CHO & 0.000 & 0.0 \\
\hline
\end{tabular}

Table 6. Steam cooked Pangasius body portion.

\begin{tabular}{lll}
\hline Steam cooked Sample-B & T-test & F-test \\
\hline Moisture & 0.000 & 0.0 \\
Protein & 0.000 & 0.0 \\
Fat & 0.000 & 0.0 \\
Ash & 0.000 & 0.0 \\
CHO & 0.000 & 0.0 \\
\hline
\end{tabular}

Table 7. Steam cooked Pangasius ventral portion).

\begin{tabular}{lll}
\hline Steam cooked Sample-V & T-test & F-test \\
\hline Moisture & 0.000 & 0.1 \\
Protein & 0.000 & 0.5 \\
Fat & 0.000 & 0.0 \\
Ash & 0.000 & 0.0 \\
CHO & 0.000 & 0.0 \\
\hline
\end{tabular}

Table 8. Steam cooked Pangasius tail portion).

\begin{tabular}{lll}
\hline Steam cooked Sample-T & T-test & F-test \\
\hline Moisture & 0.000 & 0.0 \\
Protein & 0.000 & 0.3 \\
Fat & 0.000 & 0.0 \\
Ash & 0.000 & 0.0 \\
CHO & 0.000 & 0.0 \\
\hline
\end{tabular}

\subsection{Fatty Acid Composition of the Pangasius Fillets}

The fatty acid composition as well as lipid quantities can be affected by the use of heat treatment to change the fat content of the fillets by using different heat treatments such as the microwave, steam and boiling depending upon the size 
of the meat, heat surface area, nature of the fish species and the heat temperature [11]. The fat content mainly SFA and MUFA is affected by the microwave cooked method and it is established $[12,13]$. It was reported that the heat treatment causes the increase or decrease the change of the fat content. The various fish fatty acid profile can be affected by various cooking methods it was reported given [14-19].

The composition of the fatty acid such as the SFA, MUFA and PUFA in the raw, steam and microwave- $47.15 \%, 46.73 \%$ and $46.91 \%$ respectively. The heat treatment affected the fat content of the SFA and it was changed from $47.15 \%$ to $46.93 \%$, in case of treated samples, the reduce in the content of the saturated and mono-unsaturated fatty acid is increased or decreased to more than one percent after heat treatment. The MUFA content is constituted within the range of up to $40.41 \%$ to $41.00 \%$, in this result established, the fatty acid composition changed by the treatment to up to $0.59 \%$ was reported. The PUFA content is increased after heat treatment and constituted the range of up to $12.45 \%$ to $12.53 \%$ respectively. in the present study, the defatted Pangasius fish fillets constituted more amount of saturated and mono-unsaturated fatty acid and it is reduced by use of the different heat treatment such as the microwave, steam and grilled and present microwave cooking method it could be used to change or affect the SFA, MUFA and PUFA content of the fatty acid in the raw and the cooked meat. In the present research purpose the removal of the saturated and mono unsaturated fatty acid can be used to cause heart disease and affect market fetching rate.

The present research proposed to use of steam cooking method were held by the use of normal stainless vessel to filled water covered with perforated plate then fillets were kept on the plate it was maintain $98^{\circ} \mathrm{C}$ for 15 minutes. Fatty acid composition was affected after heat treatment. The SFA and MUFA content were reduce while increase the PUFA content. mineral and proximate composition was increased. Raw Pangasius meat contains head portion of saturated fatty acid-53.04\%, mono-unsaturated fatty acid-40.7\% and polyunsaturated fatty acid- $7.06 \%$. Body portion of saturated fatty acid- $51.77 \%$, mono-unsaturated fatty acid- $40.44 \%$ and polyunsaturated fatty acid-7.06\%. Ventral portion of saturated fatty acid-50.37\%, mono-unsaturated fatty acid- $40.47 \%$ and poly-unsaturated fatty acid-7.07\%. Tail portion of saturated fatty acid- $46.79 \%$, mono-unsaturated fatty acid-39.83\% and poly-unsaturated fatty acid- $6.94 \%$. Steam heat treatment was used to reduce saturated and mono-unsaturated fatty acids and retention of poly-unsaturated fats after defatted meats.

Table 9. Fatty acid composition of Pangasius fillets.

\begin{tabular}{|c|c|c|c|c|c|}
\hline Compounds & Fatty acids & Head portion & Body portion & Ventral portion & Tail portion \\
\hline C 4: 0 & Butyric acid & 0.12 & 0.32 & 0.24 & 0.15 \\
\hline C 12: 0 & Lauric acid & 0.00 & 0.00 & 0.00 & 0.00 \\
\hline C 14: 0 & Myristic acid & 5.45 & 5.64 & 5.36 & 5.38 \\
\hline C 14: 1 & Myristoleic acid & 0.00 & 0.00 & 0.00 & 0.00 \\
\hline C 15: 0 & Pentadecanoic acid & 0.34 & 0.36 & 0.33 & 0.31 \\
\hline C 15: 1 & Cis-10 Pentadecanoic acid & - & - & - & - \\
\hline C 16: 0 & Palmitic acid & 31.45 & 31.53 & 31.54 & 31.33 \\
\hline C 17: 0 & Heptadecanoic acid & 0.43 & 0.46 & 0.42 & 0.41 \\
\hline C 17: 1 & Cis-10 Heptadecanoic acid & - & - & - & - \\
\hline C 18: 0 & Stearic acid & 7.37 & 7.58 & 7.47 & 7.33 \\
\hline C 18: $1 \mathrm{t}$ & Vaccenic acid & 36.04 & 36.06 & 36.03 & 36.01 \\
\hline C 18: $2 \mathrm{t}$ & Linolelaidic acid & 6.16 & 6.18 & 6.09 & 6.04 \\
\hline C $18: 2 \mathrm{n} 6 \mathrm{c}$ & Linoleic acid & 0.18 & 0.16 & 0.19 & 0.15 \\
\hline C 18: 3 n3 & $\alpha$-Linolenic acid & 0.59 & 0.57 & 0.55 & 0.54 \\
\hline C 13: 3 n6 & $\Upsilon$-Linolenic acid & 0.13 & 0.15 & 0.16 & 0.12 \\
\hline C 20: 2 & Eicosadienoic acid & 0.56 & 0.54 & 0.52 & 0.53 \\
\hline C 20: $4 \mathrm{n} 6$ & Arachidonic acid & 0.25 & 0.27 & 0.23 & 0.24 \\
\hline C 20: 3 & Dihomo- $\gamma$-linolenic acid & - & - & - & - \\
\hline C 21: 0 & Henicosanoic acid & 0.52 & 0.54 & 0.50 & 0.53 \\
\hline C 22: 0 & Behenic acid & 0.94 & 0.95 & 0.97 & 0.93 \\
\hline C 22: $1 \mathrm{n} 9$ & Erucic acid & 0 & 0 & 0 & 0 \\
\hline C 22: 2 & Docosadienoic acid & 0.03 & 0.01 & 0.04 & 0.02 \\
\hline C 22: $6 \mathrm{n} 3$ & Docosahexanoic acid & 0.26 & 0.24 & 0.22 & 0.23 \\
\hline C 23: 0 & Tricosanoic acid & 0 & 0 & 0 & 0 \\
\hline C 24: 0 & Lignoceric acid & 0.33 & 0.31 & 0.34 & 0.31 \\
\hline C 24: 1 & Nervonic acid & 0.83 & 0.85 & 0.85 & 0.80 \\
\hline Unknown & & 3.7 & 2.06 & 12.18 & 1.99 \\
\hline Total & & 100 & 100 & 100 & 100 \\
\hline
\end{tabular}

Table 10. Average fatty acid composition

\begin{tabular}{|c|c|c|c|c|}
\hline Samples & cooked meat of head portion & Cooked meat of body portion & Ventral region & Tail portion \\
\hline Saturated fatty acids & 46.95 & 47.69 & 47.17 & 46.68 \\
\hline Mono-unsaturated fatty acids & 39.94 & 39.99 & 39.96 & 39.82 \\
\hline Poly-unsaturated fatty acids & 8.16 & 7.88 & 8.00 & 7.87 \\
\hline
\end{tabular}




\subsection{Minerals Composition of Pangasius Fillets}

The mineral composition of the raw and cooked meats of the fillets. It is established that the sodium content of the raw fillets is $501.5 \mathrm{mg} / \mathrm{kg}$ and for the microwave and fried fish it is not significantly changed it was reported [20].

The different heat treatment methods such as microwave method, grilled and the steam cooked method are followed. The mineral composition of the steam cooked fillets to be found it in less and after heat treatment there is an increase in the mineral composition such as the $\mathrm{Na}, \mathrm{P}, \mathrm{Fe}, \mathrm{Ca}, \mathrm{Mg}$ and $\mathrm{Zn}$ studied in the fish fillets. The sodium content of the grilled cooked ventral portion to be found it range of 1731 ppm and in tail portion of meat content it is of $1735 \mathrm{ppm}$. The phosphorous content of the head portion of fillets is 4068 ppm and in tail meat it is $4061 \mathrm{ppm}$. The iron content of the head portion of fillets is found to be in range of $39 \mathrm{ppm}$ and in tail portion of meat it is of $35 \mathrm{ppm}$. The zinc content of the body portion of fillets is found to be in range of $588 \mathrm{ppm}$ and in ventral portion of meat it is of $580 \mathrm{ppm}$.

The calcium content of the head portion fillets to be found to be in the range of $2668 \mathrm{ppm}$ and in tail meat it is of 2654 $\mathrm{ppm}$. The magnesium content of the head portion is found to be in the range of $268 \mathrm{ppm}$ and in tail portion it is of 259 $\mathrm{ppm}$. It can be explained that the minerals composition of the both it can be either increased or decreased after heat treatment. After heat treatment, the mineral composition in raw fillet is increased and in cooked fillet it is increased gradually.

Table 11. Minerals composition of Pangasius meat.

\begin{tabular}{|c|c|c|c|c|c|c|}
\hline Samples & Phosphorous (P) ppm & Iron $(\mathrm{Fe}) \mathrm{ppm}$ & Zinc (Zn) ppm & Calcium (Ca) ppm & Magnesium (Mg) ppm & Sodium (Na) ppm \\
\hline Steam -H meat & 4068 & 39 & 583 & 2668 & 268 & 1732 \\
\hline Steam $-B$ cooked meat & 4063 & 37 & 588 & 2662 & 263 & 1736 \\
\hline steam $-\mathrm{V}$ cooked meat & 4072 & 39 & 580 & 2659 & 267 & 1731 \\
\hline Steam-T cooked meat & 4061 & 35 & 585 & 2654 & 259 & 1735 \\
\hline
\end{tabular}

\section{Conclusion}

The present research was carried out to study nutritional composition of defattening of catfish (Pangassius hyphoththalmus) fillets. This study focused on analysis of proximate, fatty acid and mineral composition from raw and steam cooked fillets. Proximate composition gradually increased after heat treatment. Main composition affect moisture and fat content gradually decreased and ash and protein content was increased after heat treatment. Fat composition of fillets was affected heat treatment and it is mainly focused on the saturated and mono-unsaturated fatty acid composition and poly un-saturated fatty acid. After heat treatment the defatted meat nutritional composition such as proximate composition moisture and fat content was gradually decreasing from the raw composition. Ash and protein content was gradually increase after heat treatment. Saturated and mono-unsaturated fatty acid was affected by heat treatment this content was gradually decrease from the raw composition and poly un-saturated fatty acid was increased after heat treatment. After heat treatment SFA and MUFA content decreased and PUFA content was increased. Mineral composition gradually increased after heat treatment.

\section{References}

[1] Jeyakumari, A., Janarthanan, eG., Chouksey, M. K. and Venkateshwarlu, G., 2016. Effect of fish oil encapsulates incorporation on the physico-chemical and sensory properties of cookies. Journal of food science and technology, 53 (1), pp. 856-863.

[2] Long, N. V., Yang, Y., Thi, C. M., Van Minh, N., Cao, Y. and
Nogami, M., 2013. The development of mixture, alloy, and core-shell nanocatalysts with nanomaterial supports for energy conversion in low-temperature fuel cells. Nano Energy, 2 (5), pp. 636-676.

[3] Noseda, B., Islam, M. T., Eriksson, M., Heyndrickx, M., De Reu, K., Van Langenhove, H. and Devlieghere, F., 2012. Microbiological spoilage of vacuum and modified atmosphere packaged Vietnamese Pangasius hypophthalmus fillets. Food Microbiology, 30 (2), pp. 408-419.

[4] Domiszewski, Z., Bienkiewicz, G. and Plust, D., 2011. Effects of different heat treatments on lipid quality of striped catfish (Pangasius hypophthalmus). Acta Scientiarum Polonorum Technologia Alimentaria, 10 (3).

[5] Mahmoud, M. A., Chamanzar, M., Adibi, A. and El-Sayed, M. A., 2012. Effect of the dielectric constant of the surrounding medium and the substrate on the surface plasmon resonance spectrum and sensitivity factors of highly symmetric systems: silver nanocubes. Journal of the American Chemical Society, 134 (14), pp. 6434-6442.

[6] AOAC, 2000 AOAC Official methods of analysis.

[7] Kjeldahl, C., 1883. A new method for the determination of nitrogen in organic matter. Z Anal Chem, 22, p. 366.

[8] Folch, J., Lees, M. and Stanley, G. S., 1957. A simple method for the isolation and purification of total lipides from animal tissues. Journal of biological chemistry, 226 (1), pp. 497-509.

[9] Marimuthu, K., Thilaga, M., Kathiresan, S., Xavier, R. H. M. H. and Mas, R. H. M. H., 2012. Effect of different cooking methods on proximate and mineral composition of striped snakehead fish (Channa striatus, Bloch). Journal of food science and technology, 49 (3), pp. 373-377.

[10] Ersoy, B. and Özeren, A., 2009. The effect of cooking methods on mineral and vitamin contents of African catfish. Food Chemistry, 115 (2), pp. 419-422. 
[11] Gall, K. L., Otwell, W. S., Koburgier, J. A. and Appledorf, H., 1983. Effects of four cooking methods on the proximate, mineral and fatty acid composition of fish fillets. Journal of Food Science, 48 (4), pp. 1068-1074.

[12] Pikul, J. and Wojciechowska, K., 1994. Effect of coating and immersed frying of chicken carcasses on a lipids oxidation during cold storage. Gospodarka Miesna (Poland).

[13] Kolakowska, A. and Bienkiewicz, G., 1999. Stability of fish lipids during microwave heating. Acta Ichthyologica et Piscatoria, 1 (29), pp. 101-111.

[14] Nurhan, U., 2007b. Change in proximate, amino acid and fatty acid contents in muscle tissue of rainbow trout (Oncorhynchus mykiss) after cooking. International journal of food science \& technology, 42(9), 1087-1093.

[15] Weber, J., Bochi, V. C., Ribeiro, C. P., Victório, A. D. M. and Emanuelli, T., 2008a. Effect of different cooking methods on the oxidation, proximate and fatty acid composition of silver catfish (Rhamdia quelen) fillets. Food Chemistry, 106 (1), 140-146.

[16] Larsen, D., Quek, S. Y. and Eyres, L., 2010. Effect of cooking method on the fatty acid profile of New Zealand King Salmon
(Oncorhynchus tshawytscha). Food Chemistry, 119 (2), 785790.

[17] Koubaa, A., Mihoubi, N. B., Abdelmouleh, A. and Bouain, A., 2012. Comparison of the effects of four cooking methods on fatty acid profiles and nutritional composition of red mullet (Mullus barbatus) muscle. Food Science and Biotechnology, $21(5), 1243-1250$.

[18] Şengor, G. F. U., Alakavuk, D. U. and Tosun, Ş. Y., 2013. Effect of cooking methods on proximate composition, fatty acid composition, and cholesterol content of Atlantic Salmon (Salmo salar). Journal of aquatic food product technology, 22 (2), 160-167.

[19] Neff, M. R., Bhavsar, S. P., Braekevelt, E. and Arts, M. T., 2014. Effects of different cooking methods on fatty acid profiles in four freshwater fishes from the Laurentian Great Lakes region. Food chemistry, 164, 544-550.

[20] Gokoglu, N., Yerlikaya, P. and Cengiz, E., 2004. Effects of cooking methods on the proximate composition and mineral contents of rainbow trout (Oncorhynchus mykiss). Food Chemistry, 84 (1), 19-22. Merrill, A. L. and Watt, B. K., 1973. Energy value of foods: Basis and derivation (agriculture handbook no. 74). Washington: US government printing office. 